\title{
SONS OF LILITH: THE PORTRAYAL AND CHARACTERIZATION OF WOMEN IN THE APOCRYPHAL COMICS OF NEIL GAIMAN, ALAN MOORE, AND GRANT MORRISON
}

\section{Kwasu Tembo (a)}

(a) Independent researcher. Harare, Zimbabwe. Email: tembo.kwasu[at]gmail.com

\begin{abstract}
This paper examines the treatment and characterization of women, sex, identity, and gender in the lesser known or studied comics of Alan Moore, Neil Gaiman, and Grant Morrison in order to discern what such an analysis tells us about each author's engagement with the issues and debates surrounding these sociopolitical and cultural phenomena. The purpose of this study is to discern how three of the most influential writers of contemporary comics books engage with themes of gender, identity, sexuality, and trauma and, in this way, set precedents that have come to be debated and critiqued in contemporary comics scholarship and fandom. It reveals that all three writers ostensibly engage with progressive imaginings of the self, sexuality, identity, and gender as mercurial, de-centred, and subject to play and change in each of the chosen case study characters. It finds that while ostensibly progressive, all three writers simultaneously recirculate certain conceptualizations of the relationships between identity, trauma, and sexuality by taking the histories in which they emerged as assumed.
\end{abstract}

\section{Keywords}

Moore; Morrison; Gaiman; Black Orchid; Crazy Jane; Orlando; Gender; Identity; Feminism; Theory

This work is licensed under a Creative Commons «Attribution» 4.0 International License. 


\section{СЫНОВЬЯ ЛИЛИТ: НИЛ ГЕЙМАН, АЛАН МУР И ГРАНТ МОРРИСОН ИЗОБРАЖАЮТ И ОПИСЫВАЮТ ЖЕНЩИН В СВОИХ АПОКРИФИЧЕСКИХ КОМИКСАХ}

\section{Тембо Квасу (a)}

(a) Независимый исследователь. Хараре, Зимбабве. Email: tembo.kwasu[at]gmail.com

\section{Аннотация}

В данной статье рассматривается трактовка образов женщин, сексуальности, идентичности и гендера в менее известных и слабоизученных комиксах таких известных авторов, как Алан Мур, Нил Гейман и Грант Моррисон. С точки зрения автора, подобный анализ может помочь нам понять степень вовлеченности данных создателей комиксов в проблемы и дискуссии, связанные с указанными социально-политическими и культурными феноменами. Цель данного исследования - проследить, как три наиболее влиятельных автора современных комиксов трактуют темы гендера, идентичности, сексуальности и травмы и, таким образом, создают прецеденты, которые становятся предметами дебатов и критики в современных исследованиях комиксов и фандоме. Анализ показывает в зависимости от контекста и каждом конкретном случае де-центричность, динамичность и изменчивость якобы прогрессивных представлений данных писателей о самости, сексуальности, идентичности и гендере. В статье продемонстрировано, что все эти три создателя комиксов, будучи якобы прогрессивными, повторяют одновременно определенные стереотипы о взаимосвязях между идентичностью, травмой и сексуальностью, с помощью историй, в которых эти явления возникают как естественный ход событий.

\section{Ключевые слова}

Нил Гейман; Алан Мур; Грант Моррисон; Черная Орхидея; Сумасшедшая Джейн; Орландо; гендер; идентичность; феминизм; теория

\section{c) (7)}

Это произведение доступно по лицензии Creative Commons «Attribution» («Атрибуция») 4.0 Всемирная 


\section{GENDER TROUBLE: AN INTRODUCTORY OVERVIEW OF THE PORTRAYAL OF WOMEN IN THE COMICS OF MOORE, MORRISON, AND GAIMAN}

Over the past two decades, the preponderance of mainstream Occidental feminist comics has witnessed a sustained increase. Such works acclaimed for their aesthetic and narratological achievements can be culled from a range of genres, including, but not limited to: superhero/costumed crime fighter titles such as Greg Rucka and J. H. Williams IIIs' Batwoman: Elegy (2009-2010), and Sana Amanat and Stephen Wacher's revised Ms. Marvel Kamala Khan (2014-); Kelly Sue DeConnick and Valentine De Landros' revisionist exploitation comic Bitch Planet (2014-); bildungsromans such as Joe Kelly and J. M. Ken Niimuras' I Kill Giants (2008-2009), and Shannon Watters and Grace Ellis' Lumberjanes (2014-); confessional / 'comics vérité' such as Roberta Gregory's Naughty Bits (1991-2004), Lise Myhre's Nemi (1997), and Jessica Abel's La Perdida (2001-2005); Matt Fraction and Chip Zdarskys' heist drama Sex Criminals (2013-); and Brian K. Vaughn's speculative science fiction works Y: The Last Man (2002-2008) and Saga (2012-). These authors and their work, complete and ongoing, continues to not only influence but also hold the medium of contemporary comics to account by engaging, critiquing, countermanding, and overturning gender stereotypes, promoting awareness for LGBTQIA+ issues and debates, as well as promulgating alternative voices, styles, and perspectives in the medium of mainstream Western comics which has been historically dominated and mediated by white cis male aestheticonarratological perspectives and techniques. This paper seeks to explore the burgeoning moments of developments of this kind which while importantly exigent in and of themselves, are also inextricable from the deconstructive, revisionist, and satirical comics that entered the Western mainstream in the 1980s and early 1990s. As a way of re-assessing the historico-theoretical context for current feminist trends in the medium and its genres, this paper takes the characters Crazy Jane (Doom Patrol), Orlando (The League of Extraordinary Gentlemen), and Black Orchid (Black Orchid) from their respective heterocosms as dialogic case studies to explore how the pioneers of the "British turn", namely Alan Moore, Neil Gaiman, and Grant Morrison, engaged with gender and identity politics in their less academically analyzed comics.

When considering representations of sex, sexuality, gender and identity in the work of Alan Moore, Neil Gaiman, and Grant Morrison, Black Orchid (1988), Doom Patrol (2000), and Black Dossier (1999) would appear 
to be novel choices for case studies ${ }^{1}$. Even a cursory glance at each author's oeuvre suggests that there are more 'suited' targets for such a critique: Sandman (1989) for Gaiman, All-Star Superman (2005) for Morrison, Miracleman (1982) and the most obvious of all, Watchmen (1986) for Moore. In view of the centrality these texts occupy in each author's respective oeuvre and the aesthetic and narrative ethic of the superhero genre in Western comics in toto, my chosen texts could be said to be, at the very least marginal, at the very most totally apocryphal ${ }^{2}$.

However, a more fundamental question exists. Why Moore, Morrison, and Gaiman in the first place? I argue that these three authors have to be taken in conjunction with one another because together, they represent the broadest influences of the British deconstructive-revisionist style that has come to be broadly regarded as the primary paradigm of aesthetic and narrative approaches to contemporary Western comics,

1 Black Orchid is an American comic book written by Neil Gaiman, illustrated by Dave McKean, published through DC Comics as a three-issue limited series from December 1988 to February 1989. The narrative follows the journey of two female characters, Suzy and Flora who, after awakening in a greenhouse, attempt to discover who they are. Through this journey, they encounter numerous figures from the DC Comics hyperdiegesis including Batman, Swamp Thing, as well as foes who seek to exploit them and their abilities, namely Lex Luthor. Doom Patrol (a.k.a 'The Worlds Strangest Heroes') is a superhero team from the DC Comics hyperdiegesis debuting in June 1963. The team has undergone many permutations in multiple comics. They are usually considered and portrayed as a group of superheroic 'misfits' whose powers and abilities result in pervasive and longstanding feelings of alienation and trauma. The league of Extraordinary Gentleman: Black Dossier is a graphic novel based on Alaan Moore and Kevin O'Neill's The League of Extraordinary Gentleman series. As the last of the series published under DC Comics, Black Dossier was intended to read as a sourcebook for the rest of the series, in which details of character histories, such as those pertaining to Orlando, are highlighted in various styles, including prose, letters, maps, guidebooks, a lost Shakespearean folio, and magazine articles.

2 See the following for a short summary of existing scholarship on the aforementioned titles: On Black Dossier - Michael T. Besozzi's "To Blaze Forever in a Blazing World: Queer Reconstruction and Cultural Memory in the Works of Alan Moore" (2011), Communication Theses, Paper 79; HansJoachim Backe's "The League of Extraordinary Gentlemen as (Literary) History", Geschichte Im Comic, 2017, pp. 189-208; and Jess Nevins' Impossible Territories: The unofficial Companion to The League of Extraordinary Gentlemen: The Black Dossier, Monkeybrain Books, 2008. On Black OrchidSallye Sheppeard's "Entering the Green: Imagined Space in Black Orchid" in The Contemporary Comic Book Superhero edited by Angela Ndalianis, 2009, pp. 205-2016; Tara Prescott and Aaron Drucker's "Feminist Subjectivity in Neil Gaiman's Black Orchid" in Feminism in the World of Neil Gaiman edited by Sarah Cantrell, 2012, pp. 102-116; and Julie Round's "Can I call you Mommy? 1D Myths of the Feminine and Superheroic in Neil Gaiman and Dave McKean's Black Orchid" in Debating the Difference: Gender Representation and Self Regulation, Dundee, Scotland: Duncan of Jordanstone College, University of Dundee, 2010; and Mary Hancock's “Black Orchid Reborn: Neil Gaiman's Feminist Superhero", Language Arts fournal of Michigan 29(1), 2013, pp. 34-39. On Doom Patrol - Martyn Pedler's "Morrison's Muscle Mystery Versus Everyday Reality....and Other Parallel Worlds" in The Contemporary Comic Book Superhero edited by Angela Ndalianis, 2009, pp. 250-270; Clare Pitkethly's "A Rubble of Fragments: Disintegration Into Panels in Grant Morrison's Comics", ImageText, 8(2), 2015; Marc Singer's Grant Morrison: Combining the Worlds of Contemporary Comics, University of Mississippi Press, 2012; Francesco-Alessio Ursini, Adan Mahmutovic, and frank Bramlett's “Which Side Are You On? The Worlds of Grant Morrison”, ImageText, 8(2), 2015. 
specifically superhero comics, in the late 20 th and early 21 st centuries ${ }^{1}$. As a postmodern trinity of Occidental comic book writing, Morrison, Gaiman, and Moores' collective work has also provided the basis for much of contemporary comics scholarship (Sandifer and Eklund 2015; Sanders 2006; Krueger and Shaeffer 2011; Millidge 2003) ${ }^{2}$. This influence is well documented and discussed in Alan Moore: Portrait of an Extraordinary Gentleman (2003), Grant Morrison: The Early Years - Masters of the Medium (2007), Feminism in the Worlds of Neil Gaiman: Essays on the Comics, Poetry and Prose (2012), Grant Morrison and the Superhero Renaissance: Critical Essays (2015), Last Night, Superhero Saved My Life: Neil Gaiman! Et al (2016), for example.

The overarching goal of this paper is to draw attention to the fact that the work of three of the most revered and recursively lauded authors of the medium imbued the revisionist or postmodern mainstream US comics of the late $80 \mathrm{~s}$ and early $90 \mathrm{~s}$ with a narrative, aesthetic, and thematic sensibility that subsequently came to greatly influence the articulation of feminist and LGBTQIA+ issues in contemporary comics. This paper will provide a comparative analysis between three texts from the three aforementioned authors in order to draw out some of the differences, as well as continuities, in discourses of gender, sex and sexuality, notably tensions between post-structuralist arguments about the social construction of gender and the self as fragmentary, fluid, negotiable, and essentialist notions of gender identity as fixed, immutable, inherent.

The broader scholarly context for this paper is extensive. Without being exhaustive, a few orienting pieces should be mentioned, as well as their relation to the specific areas of analysis being brought into view

1 It should be noted that there are also numerous important influences from bande dessinée and other European comics traditions. For further reading, see the following examples: Piere FresnaultDeruelle's "Verbal in Comics:, Communications 15(1), 1970, pp. 145-161; Eric Maigret's "Strange Is Growing Up With Me: Sentimentality and Masculinity Among Superhero Comic Book Readers", Communication-Technologie-Societé, 13(70), 1995, pp. 79-103; Charles Forsdick, Laurence Grove, and Libbie McQuillan's The Francophone bande desinée, Rodopi, 2005; Thiery Groensteen's La Bande Desinée: Mode d'Emploi, Les Impressions Nouvelles, 2007; and Georg Denning's "Otherness and the European as Villain and Antigero in American Comics" in Comics as a Nexus of Cultures: Essays on the Interplay of Media, Discipline and International Perspectives edited by Mark Berninger, Jochen Ecke, and Gideon Haberkorne, 2012, pp. 127-139.

2 It should be noted that there also exists a body of scholarship on other Western comics traditions in which these writers are not central. See the following for examples: Hilary Chute's "The Texture of Retracing in Maryjane Satrapi's Persepolis", Women's Studies Quarterly 36(1/2), 2008, pp. 92-110; Amy Malek's "Memoir as Iranian Exile Cultural Production: A Case Study of Maryjane Satrapi's Persepolis Series", Iranian Studies 39(3), 2006, pp. 353-380; Thomas A. Bredehoft's “Comics, Architecture, Multidimensionality, and Time”, MFS: Modern Fiction Studies 54(4), 2006, pp. 869-890; Roy Bearden-White's "Inheriting Trauma in Chris Ware's fimmy Corrigan: The Smartest Kid on Earth", International fournal of Comic Art 12(2), 2010, pp. 354-366; and Kom Kunyosying's "Horror Comics Ecology: Metonomy and Iconicity in Charles Burns's Black Hole”, Interdisciplinary Studies in Literature and Environment 21(3), 2014, pp. 562-574. 
here - on the British Invasion / chosen writers and the 'British turn' in comics:Chris Murray's "Signals from Airstrip One: The British Invasion of American Mainstream Comics" (2010) in The Rise of the American Comics Artist: Creators and Contexts, edited by Paul Williams and James Lyons. Murray has also written separately on Moore and Morrison elsewhere; on Alan Moore:Annalisa Di Liddo's Alan Moore: Comics as Performance, Fiction as Scalpel (2009); University Press of Mississippi's Studies in Comics special issue on Alan Moore (2010); on Morrison: Will Brooker's "Hero of the beach: Flex Mentallo at the End of the Worlds" (2011); Steven Shaviro's "If I Only Had a Brain" in ImageText's special issue "The Worlds of Grant Morrison" (1993); on sexual violence in comics: Tammy S. Garland, Kathryn A. Branch and Mackenzie Grimes' "Blurring the Lines: Reinforcing Rape Myths in Comic Books" (2016); Christine Ferguson's "Victoria-Arcana and the Misogynistic Poetics of Resistance in Iain Sinclair's White Chappell Scarlet Tracings and Alan Moore's From Hell" (2009); on representation gender, sex, sexuality in U.S. comics and Comics Studies: Lillian S. Robinson's Wonder Women Feminism and Superheroes (2004); Carolyn Cocca's Superwomen: Gender, Power, and Representation (2017); on gender and queer studies: Kane Anderson's "Gender Studies and Queer Studies" in The Secret Origins of Comics Studies (2017).

The methodological approach to the study of comics being adopted here pursues a theoretical comparative reading over a focus on the visual elements of the case studies chosen. This, however, does not endorse a model of authorship in comics that prioritizes the scriptwriter over the draftsperson. The work of Richard Case, Dave McKean, and Kevin O'Neil is equally vital in the expression of the theoretical themes they pictorialize. The same is true of the work of many diverse voices in the contemporary comics industries, mainstream and not, that engage with the topics under analysis here - Pia Guerra and Fiona Staples being but two examples of many ${ }^{1}$. The close readings here emerge from a narratological perspective and as such, visual form, style and media are discussed as ancillaries thereof ${ }^{2}$. Due to the constraints of the approach here, this

1 See the following for further reading on Staples and Guerra's work: Diana Adesoa Mafe's "We Don't Need Another Hero: Agent 355 as Original Black Female Hero Y: The Last Man”, African American Review 48(1/2), 2015, pp. 33-48; Mihaela Precup and Dragos Manea's "Bad Girls in Outer Space: Brian K. Vaughan and Fiona Staples' Saga and the Graphic Representation of Subversive Femininity" in Bad Girls and Transgressive Women in Popular Television, Fiction, and Film edited by Julie A. Chappell and Malory Young, 2017, pp. 253-282; and Kwasu D. Tembo's "Magical Negress: Re-Reading Agent 355 in Brian Vaughan's Y: The Last Man." Open Cultural Studies, 2019. pp. 161-173.

2 The literature review provided on page 5-6 represents some of the best analysis of comics from a host of perspectives that include detailed accounts of historiographical, sociopolitical, economic, cultural, linguistic, and aesthetic issues and debates in comics. These should be referred to for detailed analyses of visual form, style, and media in comics and comics studies. 


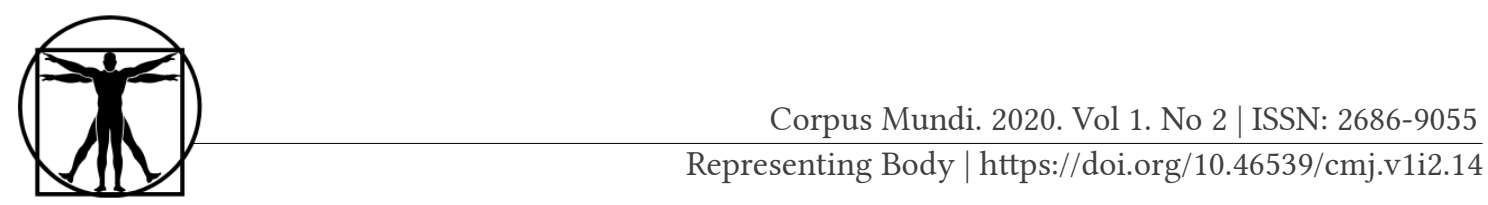

paper cannot perform a comprehensive analysis of existing debates about the representation of gender violence in US comics, for instance, Gail Simone's work on 'Women in Refrigerators' and its subsequent discussion and elaboration in both fan and academic contexts ${ }^{1}$. However, in mentioning it, this paper acknowledges its indebtedness to this body of scholarship and, in some small way, seeks here to contribute to it. As grounding for the comparative analysis of the comics, this paper is also indebted to not only Kristeva's ideas concerning the Chora as I apply them to Morrison, but other post-structuralist approaches to the self as mutable, fragmented, fluid, and de-centred, specifically the machinic and rhizometric analyses of Giles Deleuze and Felix Guattari ${ }^{2}$. My critical methodology here has also been influenced by Donna Harraway and Susan Bordo's respective discussions of the social construction or performance of gender, and particularly the way this relates to embodiment and representation ${ }^{3}$. I will also briefly note that due to the widespread engagement of various critical voices, academic and not, with the chosen authors and, to a lesser degree, the chosen case studies, the methodology of this paper has tried to represent and acknowledge this variety of analysis and commentary by referring to sources that blur the lines between various forms of academic scholarship and more generalaudience and fan-based comics criticism. These include fan annotations,

1 See the following for further reading on Feminist Comics Scholarship: Anna Kerchy's "Picturebooks Challenging Sexual Politics: Pro-Porn Feminist Comics and the Case of Melinda Gebbie and Alan Moore's Lost Girls", Hungarian Journal of English and American Studies, 2014, pp. 121-142; Elizabeth Marshall and Leigh Gilmore's "Girlhood in the Gutter: Feminist Graphic Knowledge and the Visualization of Sexual Precarity”, Women's Studies Quarterly 43(1/2), 2015, pp. 95-114; and Tammy S. Garland, Kathryn A. Branch, and Mackenzie Grimes' "Blurring the Lines: Reinforcing Rape Myths in Comic Books”, Feminist Criminology 11(1), 2016, pp. 48-68.

2 See my work on Superman in this regard for further reading: "Pax in Terra: Superman \& the Problem of Power in Superman Returns \& Man of Steel.” Postscriptum: An Interdisciplinary Journal of Literary Studies: Bengal, Sarat Centenary College, July 2017; "Re-theorizing the Problem of Identity and the Onto-Existentialism of DC Comics' Superman." 50 Years + - The Age of New French Theory (1966-1970), Word \& Text: A Journal of Literary Studies \& Linguistics: Cardiff University, 7, 2017. pp. 151-168; "Reconsidering Immortality, Consumption, and Tragedy in the Narrative Structure of DC Comics' Superman." The Quint: An Interdisciplinary Quarterly From the North: University College of the North, 10.1, 2017. pp. 109-135; "A Brain in A Vat, An Earth in a Bottle: Paranoiac Horror \& the Latent Panopticism of Superman in Red Son." Messengers from the Stars: On Science Fiction \& Fantasy: University of Lisbon, 3, 2018; “Among Them But Not One of Them: A Xenological Exploration of the Otherness and Power of DC Comics' Superman." Caietele Echinox, Romania, 34, 2018. pp. 181-199; "Superman, Power, Identity, \& Otherness in the Golden Age of Modern Comics." Coils of the Serpent: Journal for the Study of Contemporary Power, 2019.

3 Susan Bordo's Unbearable Weight: Feminism, Western Culture, and the Body University of California Press, 2003; and Donna Haraway's “A Manifesto for Cyborgs: Science, Technology, and Socialist Feminism in the 1980s", in The Norton Anthology of Theory and Criticism. Ed. Leitch, Vincent B. New York: W. W. Norton \& Company, Inc., (2010 [1985]), pp. 2190-2220 in particular. 
undergraduate essays, blog posts and peer-reviewed chapters in academic collections being listed together.

In performing critical close readings of these seemingly 'outside' case studies, this paper seeks to reexamine how each author rejects or reenforces gender and identarian centers in terms of the onto-existential issues and debates surrounding the self and the body. As such, this analysis is also not intended to read as an encomium of the 'patriarchs' of modern comics in a way that exonerates their respectively numerous and problematic examples of gender insensitivity. Instead, it is intended to expose work that readers and scholars alike might categorize as marginal to erasure, and in so doing, add such work to the assemblage of criticism of their respective oeuvres as valuable content that further informs, alters, or problematizes perceptions of both the works and their authors.

In view of the focus of the article as a whole, it would be helpful in this opening section to establish the ways each writer approaches and represents gender, sex, sexuality and gender violence in their work as a whole, and how this has been debated in the existing critical literature. When looking at the commentary and work of these three authors and their representation of sex, sexuality, gender and violence, a consensus can be assumed concerning a latent hierarchy of offense. This position would lead one to assume, in view of Morrison's critique of Moore for instance, that Moore's comments about his depiction and characterization of women are problematic, reductive, short sighted, or willfully ignorant. Worse, that they can even be read as instances of rape apologism. The counterargument could also be assumed; namely, that Morrison's critique in this regard is as problematic, reductive, short sighted, and willfully ignorant as Moore's. One could claim that a refusal to present the scale of sexual violence in contemporary comics similarly makes one a rape apologist. This could be said to be hypocritical. Similarly, due to Gaiman's more ostensible participation in projects, across a variety of media including comics, film, and television, that seemingly more openly engage with and pursue sociopolitical and cultural concerns of justice, particularly in terms of the contemporary issues and debates concerning race and gender, one could assume that Gaiman is somehow not as liable to criticism in the same way as either Morrison or Moore.

Commenting on Jacques Derrida's marginal approach to philosophy (and its margins) in Margins of Philosophy (1972), Maira-Daniella Dick notes in The Derrida Wordbook (2013) how there is a "complication qua revelation or unveiling, that takes place through the marginal of framing agency of parenthesis, which not only marks but enacts framing; and in doing so, illustrates in its performance, at the margins of commentary, so 


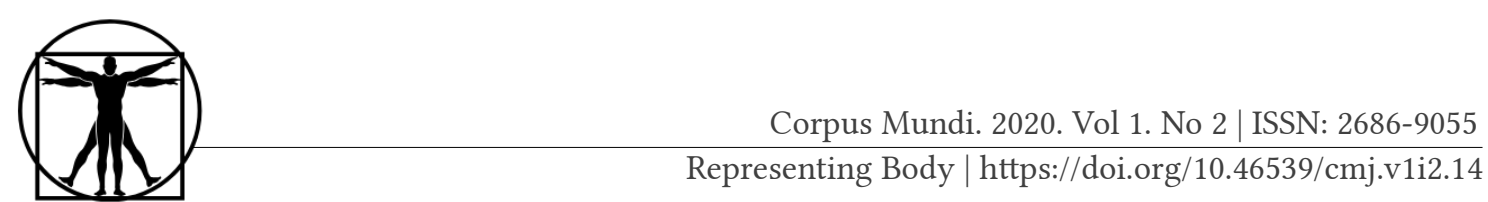

to speak, the margins, the frames by which commentary, complicating itself unveils in itself the truth in framing" (Dick, 2013, p. 112). This insight has influenced this paper's approach in that, instead of acquiescing to the consensus view of the characterization and representation of women in the mainstream or rather well known comics of Moore, Morrison, and Gaiman, this paper seeks to analyze the comparatively marginal work of these authors to see what characterization and representation (really) looks like in the umbra of critical and consumer spotlights, and what typically unnoticed or non-discussed insights can be gleaned therefrom in terms of the issues and debates between sex, identity, gender, and violence and how each author engages with them.

As noted in Laura Hudson's "Grant Morrison Talks Straight About Superhero Sexism and the 'Death Spiral' of Comic Books" (2011) for Comicsalliance, Morrison has expressed numerous views concerning sexism in superhero comics, the disturbing recurrence of rape in the work of his idol/rival Moore, and its problematic occurrence as a central device in numerous seminal texts of the typically accepted 'cannon' of great modern Western superhero comics and graphic novels. Regarding the retroactive addition of a rape scene in Brad Meltzer's Identity Crisis (2004) run for example, Morrison comments on comics and misogyny stating that

[i]t's hard to tell because most men try to avoid misogyny, really they do, in this world we live in today. It's hard for me to believe that a shy bespectacled college graduate like Brad Meltzer who's a novelist and a father is a really setting out to be weirdly misogynistic. But unfortunately when you're looking at this beloved character who's obviously been ass-raped on the Justice League satellite, even saying it kind of takes you to that dot dot dot where you don't know what else to say. (Morrison, 2011)

Moreover, Morrison specifically isolates the work of Moore as a key example stating:

I pick [an issue of Marvelman] up and there are $\mathrm{f}^{* * *}$ two rapes in it and I suddenly think how many times has somebody been raped in an Alan Moore story? And I couldn't find a single one where someone wasn't raped except for Tom Strong, which I believe was a pastiche. We know Alan Moore isn't a misogynist but $\mathrm{f}^{* * *}$, he's obsessed with rape. I managed to do thirty years in comics without any rape! (Morrison, 2011)

However, Jaynova's post for Threatqualitypress titled "I love Grant Morrison but..." (2012) correctly draws attention to the latent hypocrisy of Morrison's critique of Moore and rape by highlighting the author's problematic relationship with gender and identity issues in his own work: 
So that wasn't an implied rape scene in Hellblazer when the father and his friends invade the daughter's room? And I supposed Lord Fanny's rape, shown twice in the Invisibles, doesn't count? You could make the case that Ragged Robbin's rape doesn't count because it was a false memory. However, you can't write off the Crazy Jane was raped by her father off panel, and then by a stranger in a church on-panel. Maybe I'm being nit-picky because I've read a lot of Morrison in the past year, so it's all fresh, but still...that's a lot of rape for someone who doesn't put rape in comics. (Jaynova, 2012)

Being ostensibly more intermedial that either Moore or Morrison, Gaiman's work has received far more academic attention than Morrison's corpus. Moreover, Gaiman's ostensibly more progressive ouvre, specifically his Sandman series, has been discussed by numerous scholars (Castaldo 2004; Elder 2007; Indick 2007; Laity 2006; Rauch 2003; Reed 2008; Sanders 2006; Saxton 2007; Sharkey 2008). The author's views on gender, sexuality, and identity emerged recently in an interview for LiteraryHub titled "On Writing the Comics - And Queer Characters - We Need: Neil Gaiman and N.K. Jemisin in Conversation" (2018). In an exchange concerning representation, transgenderism, and the changing sociopolitical and cultural mores over acceptable and indeed necessary content of contemporary comics, Gaiman, unlike Morrison, offers an ostensibly progressive view:

NG: I was asked yesterday, somebody said "Sandman was the first place they ever encountered gay characters, lesbian characters, or trans characters.

Would you write them like that now?” Well, no.

NKJ: Things have changed. You've changed.

NG: Things have changed. And because now there are lots of fantastic trans people making comics and telling their own stories. And I no longer would go, "hang on, I have trans friends. I am not seeing people like my trans friends in the comics that I am reading. So I am going to put people like my friends in my comics, because that's reflecting my world." By the way, if you are a 15-year-old boy in Middle America reading my comic, I want you to meet people that you aren't otherwise going to meet. (Gaiman 2018)

However, like Rodney Sharkey's "Being' Decentered in Sandman: History, Dreams, Gender, and the 'Prince of Metaphor and Allusion" (2008), Brisbin and Booth's "The Sand/wo/man: The Unstable Worlds of Gender in Neil Gaiman's Sandman Series" (2013) draws attention to some problematic gender and identity instances in Gaiman's most lauded work. This criticism redounds to the claim that Sandman is, on close inspection, 


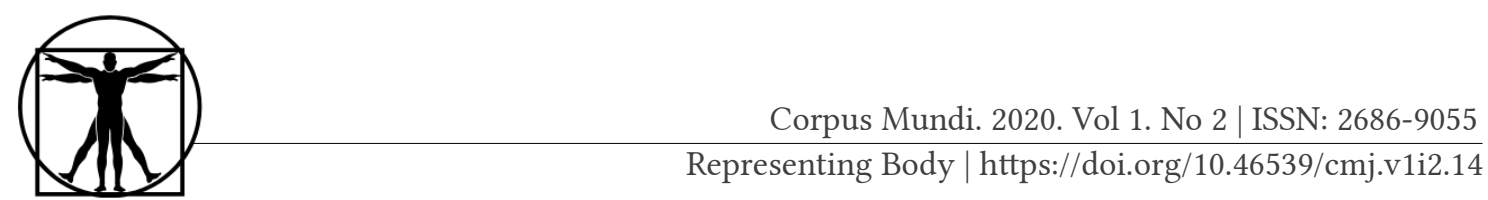

transphobic. Simon Domoney-Lyttle and Guillaume Lecomte of University of Glasgow's Comics Reading Group (2017) attempt to unpack and investigate the allegation by taking into account historical, artistic, and cultural context asking:

given that Sandman was published about 25 years ago, do the creators lack the current terminology to talk about the trans experience? Conversely, are they trying to publicly open up the discussion of gender identity? And where we can see it being transphobic, are there obvious occurrences of transphobic writing and/or illustration? (Domoney-Lyttle and Lecomte, 2017)

The entirety of Brisbin and Booth's article, and various analyses of it, have focussed on Gaiman's treatment of a trans character, Wanda, and onto-existential questions regarding the levels of inextricability in the relationship between gender, identity, and embodiedness. While the character's considerations, fears, deliberations, and pressures regarding sexual augmentation surgery, access (in this case denied) to psycho-spiritual trials (the Moon Trial), Domoney-Lyttle and Lecomte suggest that a debate over whether Wanda's storyline is transphobic misses the point in terms of the broader discussion of gender-based issues and debates in the comic and the industry (including the issues and debates surrounding other characters such as Lord Fanny in The Invisibles by Morrison, and Bill/ Promethea in Promethea by Moore). They conclude the Brisbin and Booth's argument "doesn't take into account is the lack of understanding of the idea of gender fluidity" and, further, "suggest that it is probably fair to surmise that Sandman is trying to start a conversation about gender fluidity, identity and representation" while conceding that "some aspects of the conversation do not fall in line with how we see gender today (the proverbial liberal we'), but [in the narrative] the ideas are being challenged" (Domoney-Lyttle and Lecomte, 2017; emphasis mine).

Here, it would seem that Morrison and Gaiman's approach to gender-based issues in the medium and genre is polarized. On the one hand, we have Morrison offering hypocritical critiques and commentaries against other archons of the industry, regardless of how factually sound. On the other, we have Gaiman who critics convincingly argue has ostensibly attempted to use his work to consciously and conscientiously draw attention to these very same issues and debates, thereby using the privilage of his cis white heterosexual male voice to create dialogue, as well as open both he and his work up to criticism along these lines. "It is clear" argue Domoney-Lyttle and Lecomte "that Sandman was attempting to subvert fairy tale expectations, so it is fair to say that gender and sexuality expectations are also being subverted. But does this absolve the focus 
on the gendered body?" (Domoney-Lyttle and Lecomte, 2017). While seemingly apologetic, the authors raise an interesting and important point central to this analysis: how does each author approach the myriad philosophical, sociopolitical, and cultural problems associated with the difference or inextricability between body and identity, self and sex?

There is much scholarly and non-academic commentary on the controversial history of gender-based violence, especially rape, in Moore's work. Joe Linton and Robert Deries note in "The Horror of Rape: Alan Moore, Lovecraft, and Neonomicon" (2015) for Facts in the Case of Alan Moore's Providence, there are "notable instances" of sexual violence that "include the rape of [...] Abby in Swamp Thing" [and that] sexual violence against women is one of the key themes of several of Moore's works" (Linton and Deries, 2015). Other examples in this trend of Moore scholarship include Anna Marshall's "Not So Revisionary: The Regressive Treatment of Gender in Alan Moore's Watchmen" (2016), Erica Masserano's "An Act of Social Magic: Class, Gender and Modernity in Alan Moore's From Hell" (2012), and Mathew Green's "She Brings Apocalypse: Sex, Imagination and Redemptive Transgression in William Blake and the Graphic Novels of Alan Moore" (2011). Similarly, Kelly Kanayama's "That Alan Moore Interview: A Response for Women Write About Comics" (2014), Sally Ferguson's "Women and Watchmen: Opening Alan Moore's Refrigerator" (2014), Todd A. Comer and Joseph Michael Sommers' Sexual Ideology in the Works of Alan Moore: Critical Essays on the Graphic Novels (2012), Robyn Kenealy's "Alan Moore (and I) Have Some Gender Issues" (2009), and "Alan Moore's Misogynistic Legacy" (2009) for A Fistful of Science all offer lengthy takes on Moore and the troublingly consistent history of sexual violence in his oeuvre. In response, Moore offers the following justification in Pádraig Ó Méalóid's "Last Alan Moore Interview" (2014):

Well, quite obviously, the safest and most comfortable option would have been to go along with a censorious status quo and simply not refer to sexual matters, even obliquely. Indeed, as I remember, this is exactly the option that most of my contemporaries in the field back then tended to make their default position, since they were understandably reluctant to displease their editors and thus to jeopardize their chances of future employment. It seemed to me, however, that if comics could not address adult matters - by which I meant a great deal more than simply sexual issues - then they could never progress to become a serious and accepted artistic medium, and would never amount to anything much more than a nostalgic hobby for ageing teenagers. To my mind [...] it seemed that such a potentially astonishing medium deserved more than this. Along with political and social issues, I elected to make sexual issues a part of my work. [...] So perhaps it is the next decision that I made wherein I am at fault: my thinking was that sexual violence, including rape and domestic abuse, should also feature in 


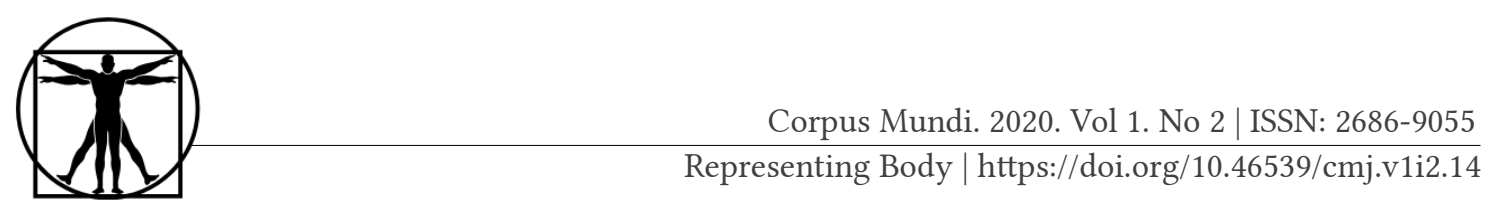

my work where necessary or appropriate to a given narrative, the alternative being to imply that these things did not exist, or weren't happening.(Moore, 2014)

Moore goes on to further claim that

[R]ape did not exist in the comic books of that period, save for the occasional permissible off-panel rape, such as when a tavern dancing girl might be pushed back into the hay by a muscular barbarian, her lips saying no but her eyes saying yes. Other than this, no overt sexuality of any kind existed in the mainstream comic books of that era, with the last of the underground comix having bitten the dust during the previous decade. (Moore, 2014)

Here, a critic of Moore could claim that the he is being reductive and short sighted. Consider this statement following Ó Méalóid's questioning of his depictions of rape: "Why should sexual violence be ring-fenced when forms of violence every bit as devastating are treated as entertainment? If I may venture an answer to my own question, might it be because the term 'sexual violence' contains the word 'sexual', a word relating to matters traditionally not discussed in polite society?" (Moore, 2014). That same critic could also argue that Moore is both confusing and conflating the issue of his problematic depictions of sex and sexual violence with the broader issues and debates surrounding moral and legal censorship. In view of Gaiman's seemingly conscious and conscientious exploration and inclusion of sexual violence and broader gender-based discourses in his work intimated above, the underlying question here is the extent to which Moore does the same. Does Moore include sexual violence in his work in a way that ultimately presents its associated acts and their psychological and emotional consequences as exploitable, titillating spectacle at the expense of serious critique and commentary that a voice as respected as his could instantiate?

Kevin's article titled "Alan Moore, What's With All The Rapes?" (2013) for Contrarian Fanboy offers a vociferous argument against any progressive interpretation of the relationship between sexual violence and the author's work. The article's statistical approach to Moore's corpus and instances of rape and/or other forms of sexual violence within it offer damning and ostensibly insuperable evidence against Moore in this regard. According to Kevin,

there's been an instance of sexual violence (much of it shockingly offhand and quickly dismissed or forgotten) in every major work Moore has written and in many of his minor works. Every volume of The League of Extraordinary Gentlemen contains one instance of sexual violence (almost all aimed at Mina Murray). Lost Girls, his long germinating erotic adventure, veers between joyful sex and 
sexual violence so rapidly that I found myself wondering (however momentarily) if Moore even remembers the difference between the two. Neonomicon, his ode to Lovecraftian horror, features a grizzly rape. Tom Strong, his attempt to write an old- fashioned superhero comic has a rape (which is actually played as a punchline) [...] Even his earlier works (which in my opinion tend to be better than his offerings from the last ten years) have a disturbing pattern of sexual violence. Watchmen, V For Vendetta, Killing foke, Miracle Man each features a scene of sexual violence. And while many of these were treated with seriousness and humanity, still others were, in my opinion, both unnecessary and ultimately insulting. Obviously the problem is bigger than Alan Moore, but Moore is often held up as the God of comic book writing and, just as often, as the conscience of comics. This lofty status means that what he does, like featuring so much rape, deserves some added reflection. (Kevin, 2013)

At best, Moore could be seen here as willfully ignorant, in view of Kevin's critique. At worst, he could be seen as an apologist for sexual violence. The point here is that while the seemingly perennial presence of rape casts a long shadow over his work, I argue (and in view of the above perhaps even controversially) that Moore has, in the same corpus, done some interesting things with gender, the most interesting being through the character Orlando, as I will discuss later.

The above excursus has tried to show that there is a notable body of academic, industry, and consumer debates concerning the representation of gender and identity issues, rape and sexual violence in all three authors' work, but particularly in the work of Moore. In view of the ostensible attitude many of said commentators, scholars and consumers offer when confronted by rape and sexual violence in comics in general, in Moore's work in particular, one might be inclined to believe that not only said representations, but the recursiveness of said representations, is abjectly 'disturbing', 'troubling,, 'objectionable'. It is also true that a not insignificant industrial perspective that adheres to this appraisal of the situation is the product of author-to-author rivalries, and issues and debates surrounding (dis)taste, particularly between Moore and Morrison. The strange refracting/reflexive rivalry between the two authors, one whose publicity and legend within the comics industry has the air of a conflict between master and apprentice or, more accurately for the two authors, mystagogue and adept, oftentimes takes primacy over the content of the criticisms each author launches against the other. While Moore accuses Morrison of being parasitically derivative of everything Moore pioneered, invented, attempted, and failed at first, Morrison counters by labeling the former a serial contrarion who is increasingly out of touch with the zeitgeist, the readership, and the sensitivities and changing tastes and critical standards concerning not only sex and sexuality, but violence as well 


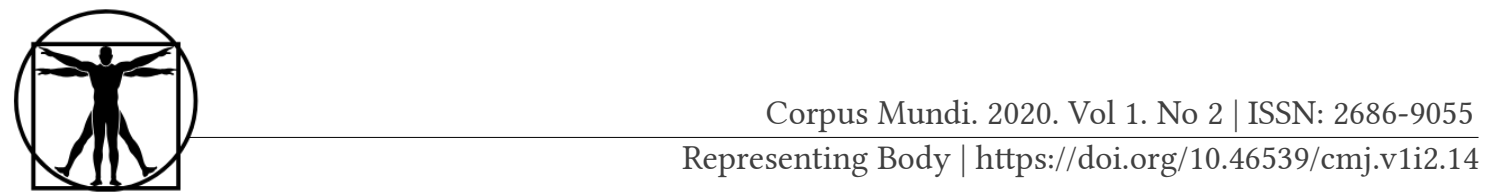

(Sneddon, 2012; Campbell, 2018). It would seem that in this quietly fraught milieu, Gaiman somehow gets a pass and is somehow immune to criticism in terms of his depiction of sex, sexuality, gender, and the female body in his comics, mainstream and marginal alike. I would counter that this middling and, compared to Moore and even Morrison, negligent critical analysis thereof is perhaps the most disturbing, troubling, or objectionable aspect of the representation of sex, sexuality, gender, female bodies, and violence among the three authors.

It is this paper's contention that while all three authors present innovative ways of re-reading the most misogynistic, racist, and otherwise prejudicial tropes of the medium, in a host of varied ways for different readerships, markets, and epochs, they are not exempt from also subtly and overtly re-inscribing these same prejudices into the medium they are said to have collectively so revolutionized. The implication of this analysis, in the last instance, is to compel the reader to look beyond the spectacular talents of each author and, following this critical comparative reading, consider just how much or how little each authors' representations and engagements with the issues and debates of sex, sexuality, gender, identity, and sexual violence really are. Beyond these contrasts and conflicts, different critical opinions within this body of scholarship, such as the 'Contrarian Fanboy' (whom I quote earlier), suggest that the fact Moore's comics often represent rape is not in itself problematic. Instead, the commentator suggests that oftentimes, the debate redounds to questions of how rape can and should be visually and narratively represented. According 'Contrarian Fanboy' and others, the more substantive problem is when rape is used as a lazy paraphrase for visceral realism, emotional resonance, and character development. The question this begs, then, is how do said authors treat these themes in their more marginal works and what can we learn from it?

\section{"I WHO HAVE DIED AM ALIVE AGAIN TODAY": RE- GERMINATION, FRAGMENTATION, AND IDENTITY IN BLACK ORCHID'S SUSAN LINDEN-THORNE}

Gaiman and McKean's Black Orchid (1988) is a three part miniseries published by DC comics. Comparatively recondite against Sandman, Gaiman's early foray into superheroic fiction is still a robust example of the author's poetic, elegiac, and oneiric style. The narrative follows two May Queen-Human hybrid females, one an adult, the other a child. Being facsimiles (known as 'blossoms') of an original character named Susan Linden, the pair undertake a journey of self discovery during which they 
encounter notable figures of the DC Universe including Batman, Swamp Thing, Lex Luthor, and Poison Ivy. The miniseries lays out the following genealogy of Susan: Original Susan, followed by Sue 1 (the first copy created from Original Susan's DNA/RNA by her friend/admirer/handler named Dr. Phillip Sylvian). Upon her (re)birth/manufacture, she becomes a costumed crime fighter operating under the nom de guerre 'Black Orchid'. Her abilities include superhuman strength, speed, agility, flight, durability, and a mystical connection to the plant realm governing all botanical life on earth known as the Green ${ }^{1}$. More important in terms of the identarian questions Gaiman's miniseries asks, Linden's blossoms are able to reincarnate through an undefined process in which the consciousness of the most recent incarnation is transferred to a new host body following the death of the previous blossom. She is later burned to death by the Chairman, one of Lex Luthor's henchmen. This gives rise to a second blossom who is the focus of the narrative, Sue 2 and her immature sisterclone self Sue Jnr. The latent implication of the sempervivum of hybridity here is that Linden is immortal. In being multiform - that is onto-existentially (physically, psychologically, and emotionally) rhizometric - the character is in a very real sense everywhere and nowhere at once. There is no central self that persists through each new germination of self following the simultaneous destruction of the previous incarnation thereof. Therefore, Linden's blossoms remember her/their old lives, their/her memories, their/her death, and other fragments of their/her experiences. This is highlighted in issue No. 1 "One Thing Is Certain" (1988) where the new incarnation of the Orchid persona is told by Dr. Sylvian, that "the OTHER one knew IMMEDIATELY", which is to say that knowledge of self in the Orchid diegesis is machinic (Gaiman, 1988). It is an assemblage of onto-existential fragments and impressions imperfectly recalled and subsequently inscribed on the latest or newest Orchid body, thereby producing an experience of fractured being for that body. Conversely, the character's auto-generative immortality points to some interesting considerations concerning primogeniture, legacy, and womanhood. If Orchid is seen as a collection of imperfect recall of previous incarnations of the persona superimposed, albeit incompletely, over, onto, or within an identical body, then Orchid's selfhood is matrilineal where she/they is/are both daughter and mother to themselves/herself.

1 In the DC Comics hyperdiegesis, the Green refers to an elemental force connecting all forms of plant life on earth. For elementals such as Swamp Thing, the Green is experienced as a type of psycho-affective realm inhabited, protected, and overseen by the collective minds of the Parliament of Trees. 
Corpus Mundi. 2020. Vol 1. No 2 | ISSN: 2686-9055

Representing Body | https://doi.org/10.46539/cmj.v1i2.14
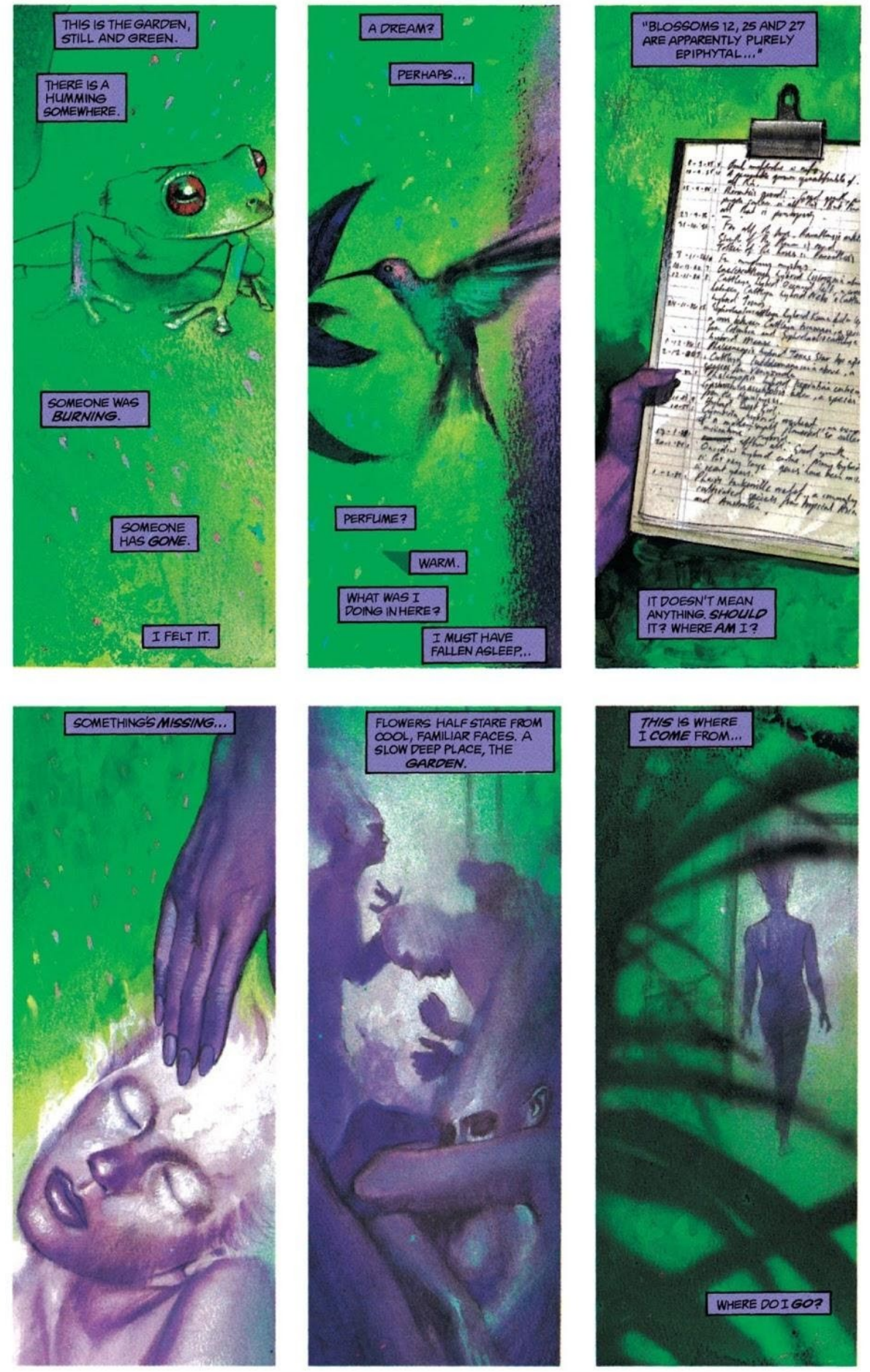

Fig. 1. From Black Orchid Vol. 1, No. 1 "One Things is Certain" (1988) written by Neil Gaiman, illustrated by Dave McKean 
The character's congenital loss of memory or imperfect recall raises agential questions in identarian terms. If an individual is (re)born fully grown but unable to recall the ontological and existential experiences that constituted said development to the terminus of maturity, one is in a position of not knowing who one is, where one came from, in Linden's case what one is, and why one came to be in this way. There are also some other seemingly latently gender-coded associations between the character, her powers/skill-set, ethic, teloi, and the actions required to bring them to fruition. For example, the obvious and reductively quintessential associations between women, fecundity, rebirth, growth and germination remain central to the character despite Gaiman's seemingly radical poststructural approach to gender, embodiedness, and identity in later works. Moreover, immediately within the first few pages of Black Orchid, and for much of the later narrative, Linden's blossom is portrayed as naked, ethereal, and powerful in their/her immortality. However, they are also submissive, naive, manipulable, docile, and in their/her case, literally "born sexy yesterday". The phrase refers to "a trope that's particular to science fiction and fantasy, in which - thanks to the power of science or magic a woman has the mind of a naive yet highly skilled child, but in the body of a mature, sexualized woman. The woman is fully grown physically, and is often skilled at something male-coded like combat or coding, but she has little experience of sexuality or social norms" (Jasper, 2017).

Sue is also shown to occupy an liminal space between being born sexy yesterday and not being born sexy yesterday enough. At the end of the series, after the remaining Susans arrive at a hidden grove in the Amazon valley to replant themselves in the relative seclusion and sanctuary of the deep jungle, Sue 2 declares: "I have too many of Susan's memories to be truly happy here" (Gaiman, 1989). Here, Sue 2's experience, however fragmentary, de-centred, or displaced, is still subtended by those same fragments she inherited. In this sense, she is plagued by a void signified by incomplete memories. As a result, she is subject to memories both beyond and within her, paradoxically binding her self to herselves with inconsistencies and incomplete narratives, and is thus unable to experience or enjoy the bliss of ignorance. In view of this use of de-centred selfhood as a narrative frame, what can the individual whose being represents but a fragment of that selfhood have in terms of agency? Sue 2 puts this paradox across rather poetically in issue No. 2 "Going Down" (1989): "In dreams we find only contradictions. I tumble into the past, awash in another's memories. I dream my sister [...] further down. Further back. The dreams are Susan...Mother" (Gaiman, 1989). In the last instance, having Sue 2 simultaneously be her own child and mother both affirms and trou- 


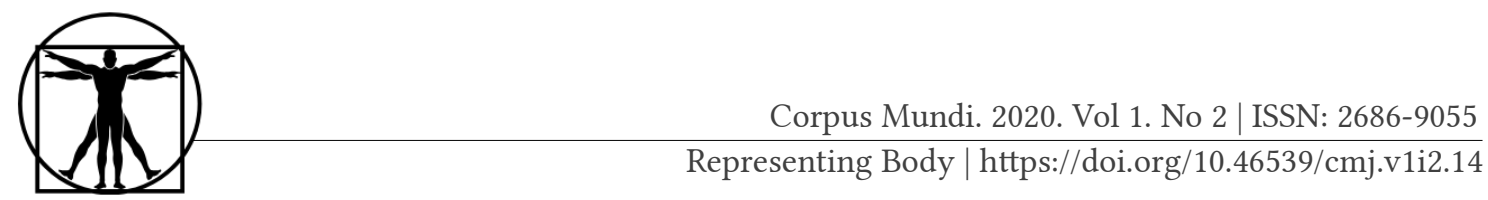

bles the quintessentially reductive construction of a woman's narrative value that limits her agential possibilities to the status of either dependent or caregiver.

\section{"HER SOUL IN DIVISION FROM ITSELF": GENDER IDENTITY, AND MENTAL ILLNESS IN DOOM PATROL'S CRAZY JANE}

Created by Morrison and Richard Case, Crazy Jane is a central member of the Vertigo incarnation of the eponymous superhero team the Doom Patrol. Appearing in Vol. 2, No. 19 "Crawling From the Wreckage" (1989), Morrison explores the issues of gender and trauma through Jane Morris, the dominant personality of Kay Challis. Challis, diagnosed with multiple personality disorder, has a variety of distinct personae in her, two of which are male, with each boasting a different superpower as a result of a gene bomb. Genius intellect Will Magnus describes her condition as follows:

her experiences resulted in what psychiatrists call DISSOCIATION. Basically,that means she developed multiple personalities to cope with the trauma. Her therapists tell me that so far they've identified SIXTY-FOUR separate personalities, each with its own name and function. And following the effects of the 'gene bomb'...each one with its own distinct meta-human ability. (Morrison, 1989)

Not only does this imply that Jane is latently omnisex, but also here, the notion of de-centred or fragmentary self resembles that explored by Gaiman, albeit limited to psychic, affective, and emotional phenomena.

Unlike Gaiman's botanical frame for Linden's blossoms' plurality of self, the provenance of Jane's multiple personalities is trauma. Like Gaiman's revelations about the back-story of the original Susan Linden, Morrisons' Jane is the victim and survivor of severe psycho-sexual childhood abuse perpetrated against her by her father (Morrison, 1989). In the first two volumes of Doom Patrol, Morrison explores the effects of this initial trauma in numerous ways that ultimately redound to an overarching albeit unoriginal construct. Morrison portrays both Jane's powers and trauma as a psycho-emotional map that simultaneously charts as well as acts as a repository for her unconscious network of selves called The Underground. Here, it could be argued that while Morrison ostensibly situates Jane within quintessential tropes subtending persistent associations of women, mental disorders, abuse, and trauma in contemporary superhero comics, holdovers from the pervasive permutations of the psychoanalytical trope of the 'hysterical woman' derived, for example, from Sig- 
mund Freud ${ }^{1}$. However, it can be equally argued that in doing so, Morrison's presentation of Jane represents a simultaneous exacerbation thereof as well as a reclamation of agency within the otherwise prohibitive and repressive frames of psycho-sexual disorder in women. Such a conclusion is derived from the fact that Jane's dissociative disorder is her superpower, one that grants her numerous types of supra-human agencies. At the same time, this power and agency is problematized by being inextricably linked to her continued suffering and the cyclicality of her trauma. In this way, the themes, issues and debates surrounding agency, dis-empowerment, and re-empowerment both orbit and emanate form the Gordian core of her character.

All of Jane's personae are born of the same childhood trauma. Morrison here characterizes the Underground as a psycho-emotional network of repression: an Underground sub(conscious)way system expressed most clearly in Vol. 1, No. 28. In the story titled "Going Underground" (1990), Cliff Steel's (also known as Robotman, an ally and teammate of Jane's) psyche enters Jane's "psychescape" as Jane lays trapped within herself in a deep cataleptic state. Jane's complete psychic withdrawal is a result of the Patrol's battle with an apocalyptic entity called the 5th Horseman which left her psychic hierarchy of self damaged by the strain she/they endured. Driver 8, one of Jane's main personalities responsible for conducting the literal and figurative 'Train of her Thought', says to Cliff: "that's why the WOMAN is cataleptic. No one down here wants to take control any more in case they get hurt" (Morrison, 1990). Aboard Jane's Underground Train, Cliff catches indistinct flashes of both Jane's selves and their personal histories in her mind. Driver 8 tells him they are "psychic fallout from K-5", the first of Jane's personae, the very same one "who endured the first ABUSE. Those tremors are still resonating" (Morrison, 1990). She continues, adding that "Crazy Jane's only ONE of the selves who keep the woman functioning. As for Kay, SHE hasn't really existed since she was five years old. She's ASLEEP in one of the deep stations" (Morrison, 1990). Driver 8 further clarifies the nature of the deep structures of the Underground when she says to Cliff that "a lot of [Jane's personae] won't come out, even for me. Some refuse to say their names. Those are the badly traumatized ones, in the deep stations of the Underground" (Morrison, 1990). It is also revealed that following her encounter with the 5th Horseman, Jane is suicidal. Driver 8 describes the situation as follows: "I think she intends to DESTROY herself and leave the rest of us trapped in a useless body. I think she's going to the WELL” (Morrison, 1990). She further

1 In such texts as Studies in Hysteria, Read Books, 1895 [2013], and Three Essays on the Theory of Sexuality, Verso Books, 1856 [2017]. 


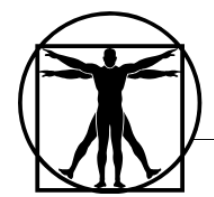

describes the Well as follows: "no one likes to talk about it. It's down on the low-level line. A terrible place. They say it leads into a buried and forgotten section of the Underground. No one's been down there since MIRANDA destroyed herself. Two years ago at Easter Time. The underground barely survived. If Jane goes into the Well, we're finished. (Morrison, 1990).

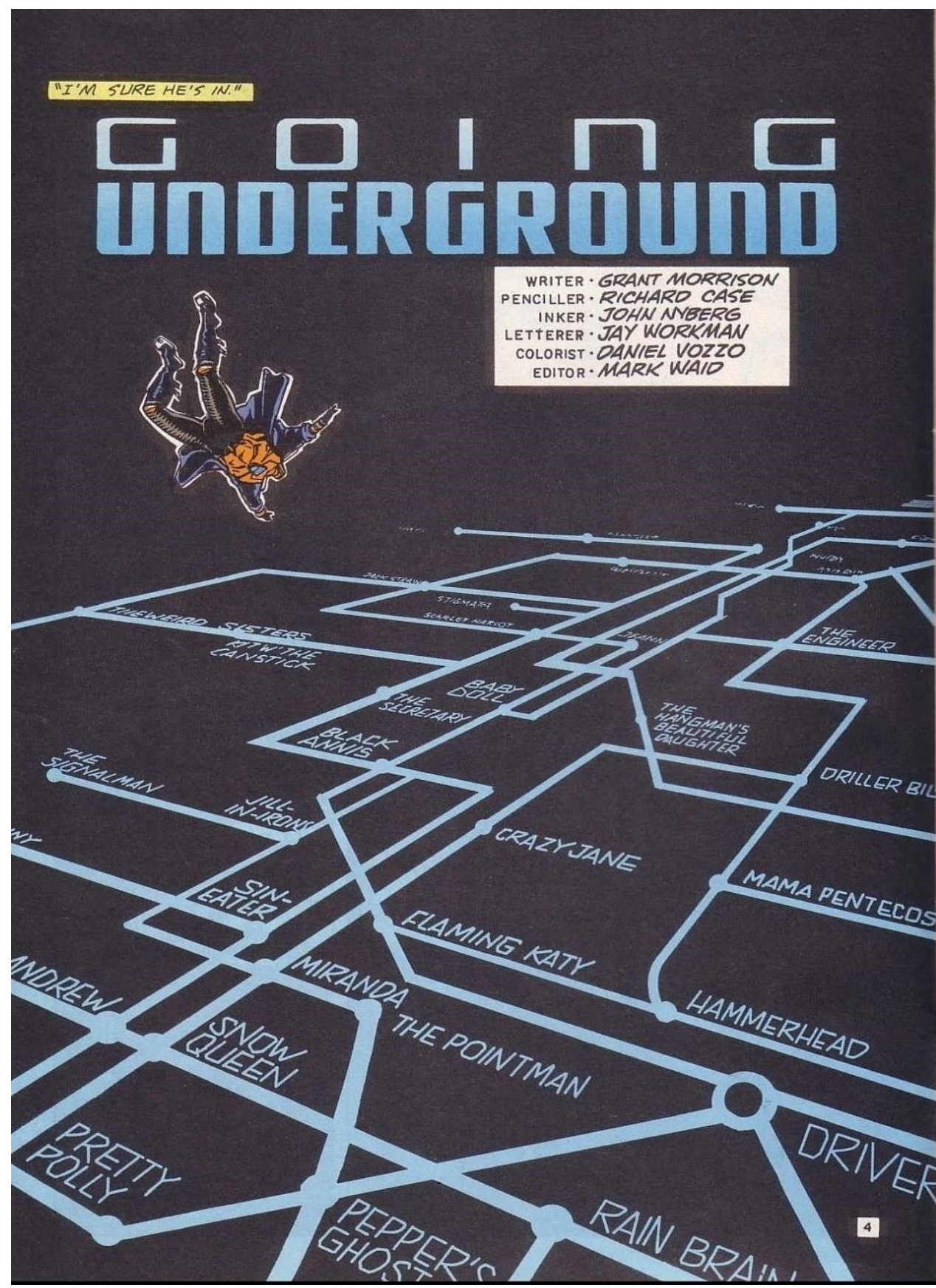

Fig. 2. From Doom Patrol Vol. 2, No. 30 "Going Underground" (1990) written by Grant Morrison, Illustrated by Richard Case 
From a psychoanalytically theoretical vantage, the personae that form Jane's Underground are products of raw psychic forces in which reside Jane's life and death drives. There are two main implications here. First, the dissolution of self or essential self-fragmentation is a prerequisite to entry into the Well and the Underground in principium. Second, the network circumscribing and also bound to The Well is Choraic in a specifically Kristevan way. Unlike Jacques Lacan's phallogocentric discourse concerning the androcentric prohibition of the power of the unconscious through the symbolic order reified by institutions including the law, politics, and language, Julia Kristeva's notion of "the semiotic Chora ordering the drives" calls for a shift in focus from the prohibitive symbolic order or phenotext to the primordial conditions and closeness associated with the genotext (Kristeva, 1980). According to Kristeva, society is subject to multitudinous sociopolitical constraints which "stop the signifying process...[and] knot it and lock it into a given surface or structure; they discard practice under fixed, fragmentary, symbolic matrices" (Kristeva, 1980). This notion is described by Kristeva as the phenotext. Kristeva describes the genotext however as an infinite space (that can be lent a topography, but never be given an axiomatic form) which includes within it "drives, their disposition, and their division of the body, plus the ecological and social system surrounding the body such as objects and pre-Oedipal relations with parents" much in the same way Jane-to-Jane interfacing through a more primary connection between her personae, the Well, and the Underground facilitate and engender similar genotextual relations (Kristeva, 1980). In this way, albeit by varying degrees of de-centredness, both the Well and the Underground cause Jane's ego or self-formulation to be decoupled from her/their affective experiences of egolessness.

\section{“I WAS 3, 203 YEARS OLD WEEK AND I ENDURE": HISTORY, GENDER, IDENTITY, AND KNOWLEDGE IN LEAGUE OF EXTRAORDINARY GENTLEMEN: BLACK DOSSIER'S ORLANDO}

"The Life of Orlando" featured in the League of Extraordinary Gentlemen comics series' apocryphal text League of Extraordinary Gentlemen: Black Dossier (1999) follows the secret history of the League's oldest member Orlando. Born Bio of Thebes in 1260 BCE, Orlando can best be described as a sexually protean adventurer, warrior, and scholar who has lived for over 3000 years. Moore portrays Orlando as both witness to and participant in numerous important events of fictional and non-fictional world histories. Interestingly, Moore uses the character's 3000 year life to 


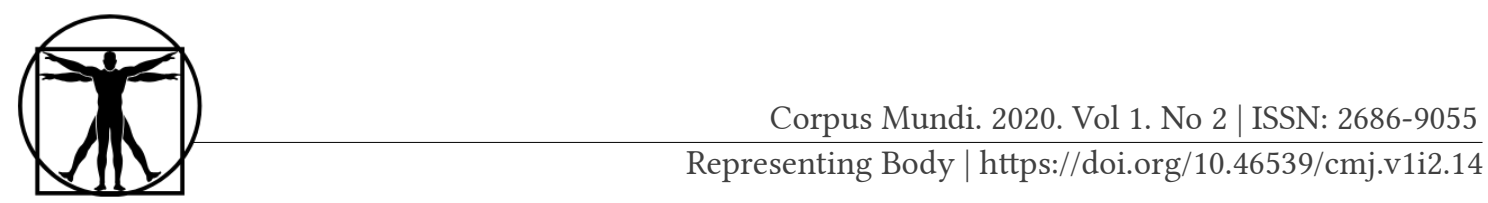

equate knowledge, experience, and history with gender, thereby drawing parallels between omni-sexuality and omni-historicity.

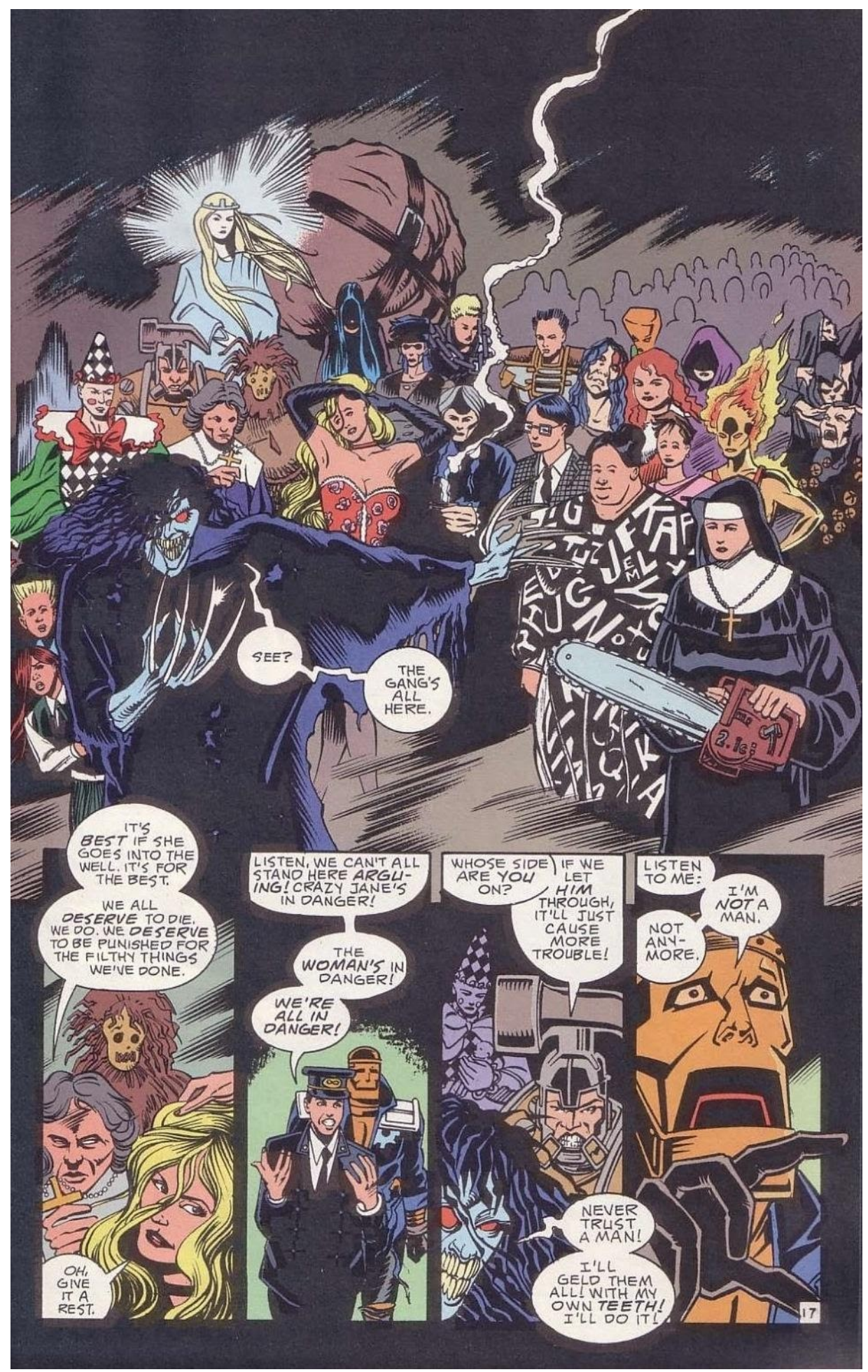

Fig. 3. From Doom Patrol Vol. 2, No. 30 "Going Underground” (1990) written by Grant Morrison, Illustrated by Richard Case 
Unlike his more controversial explorations of gender, power, identity, and violence in such texts as Watchmen and Neonomicon, through Orlando, Moore suggests that multiplicity of self or self-splitting does not lead to any sort of onto-existential diminishment. Rather, it permits an onto-existential and epistemic holism. This is directly in contrast to Gaiman's exploration of the same dialectical thematization of self splinting as reductive, which concludes that self-splitting and self-fragmentation result in an insoluble ennui that immortality, through re-incarnation, cannot salve. For Moore however, the epistemic and experiential knowledge garnered from onto-existential immortality and psycho-sexual fluidity does not prevent the experiencer, as woman, man, both, and neither, from being exposed to danger. Orlando's omnisex state also puts her/him in a position to receive boons and favors. For example, when Orlando arrives in Egypt in $1250 \mathrm{BCE}$, his/her fundamental androgyny results in her/ him becoming a favorite of Pharaoh Usarmarttim (Ozymandias). In this instance, identarian instability is construed as a boon as opposed to a malady as it is with Jane, or an agential or memorial impasse as it is with Linden. Moore's explorations of the interconnectedness between gender, identity, and history really become the main thrust of "The Life of Orlando" after Orlando becomes immortal. It is at this point that s/he becomes, the perfect metaphor for civilization, that is, human history is an omnisex embodiment of experiences, including pleasure, pain, knowledge, mysticism, fear, war, love, heartache - the so-called thousand natural shocks that flesh, regardless of sex, identity, and other permutations of embodiedness, is heir to.

In Metahistory (1973), the narratologist Hayden White notes that the construction of a history involves certain key elements. First, the chronological ordering of events within a historical field. Second, the events that constitute this chronicle are further arranged and adapted into a narrative. The nature of this narrative is 'spectacular' while also being designed to be logically coherent in terms of narrative structure; that is, it must typically have a beginning, middle, and end (White, 1973). In Black Dossier, Orlando's alternate history undoes both the process of manufacturing history and history itself as a product of this process. It then subsequently remakes or reproduces history, through an interweaving of multitudinous extradiegetic and diegetic histories in a closed, interstitial circuit of historically-minded play. This play not only is (re)produced in and through Orlando, but specifically their psycho-sexual mercurial-ness. In this way, Orlando's account ruptures the notion that the received grand narrative(s) of history are either 'natural' or originate from 


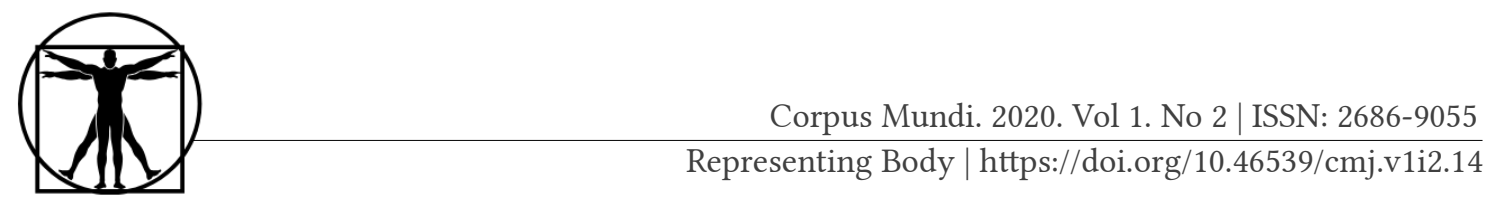

the self-presence of man and/or God. Here, the phallogocentric 'centre' from which history emanates is displaced by having Orlando be a specifically transgender witness, participant, and narrator of these omnistories.

By displacing the centre of history by consistently substituting the ontological and existential foundations of its witness/participant and, in this way dividing the centre within itself, Moore equates history with Orlando's antipodal and unstable fluctuations between woman, man, and inbetween. Here, Moore suggests that it is precisely through this play of presences that Orlando's gender oscillations provide an opportunity for the hidden, apocryphal, absent, or marginal histories of civilization to emerge from the interstices between fact and fiction, diegetic and extradiegetic, male and female (Derrida, 1978). The latent implication here is that the intra-subjectivity of Jane, Susan, and Orlando allows for the reader's perceptions, barriers, and understandings circumscribing the modes of representation of gender and identity can be at least temporarily transgressed.

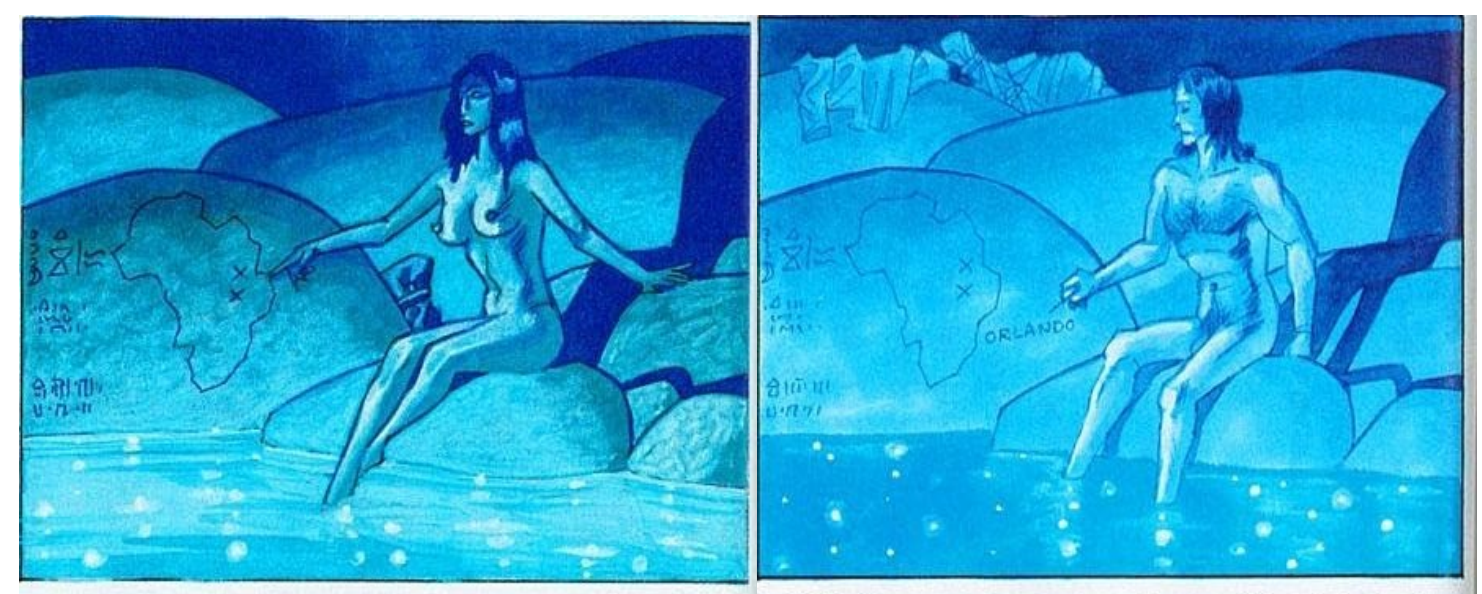

4. Bathing in its lapid, liquid flames, emerging strangely vital-3. With Prospero gone and our league disbanded, England ised, I noticed old names and a map carved at its edge. (I did seemed dull. I roamed the world, even revisiting Kor in Africa not carve my name there 'til millennia later, during the upstart and its magic pool, this time carving my name on the rock Ayesha's rule.) there beside it: 'Orlando.'

Fig. 4. League of Extraordinary Gentlemen "Black Dossier" (1999) written by Alan Moore, illustrated by Kevin O'Neill
Fig. 5. League of Extraordinary Gentlemen "Black Dossier" (1999) written by Alan Moore, illustrated by Kevin O'Neill

What are we to make of these attempts at expressing a post-structuralist approach to sex, sexuality, gender, and identity in these texts? What does Moore, Morrison, and Gaiman's work in Black Dossier, Doom Patrol, and Black Orchid reveal about each author's attempt at engaging in 
the issues and debates thereof? One way of offering a summary comment concerning the above analysis is to first consider what these deconstructive examples are predicated on, that which each text takes as assumed. While ostensibly a motley trinity of three radically different types of stories, wildly different characters under varyingly disparate circumstances, there is a through-line in terms of the affective condition of Orlando, Jane, and Sue that actively undifferentiates them. It would appear that the agential benefits and power (literal and figurative) that comes with a decentred sense of self is a secondary, and in certain ways compensatory, allotment. It so happens that the primary, unifying psycho-emotional experience each character expresses, despite their power set, epoch, and the permutations of their embodiedness is a pervasive sense of isolation and/ trauma. While each author does much to suggest that a radical cutting-off of self from self and/or of self from body is not a diminishment, much of the repressive, exploitative, and traumatic (pre)conditions which necessitate this reclamation of self-splitting as a type of agency remain assumed. All three authors do much to try and bend the psycho-emotional, sexual, and embodied results and outcomes of these conditions. However, they seemingly cannot disentangle them from their assumed conditions. One could argue that this was impossible for Morrison and Gaiman to do, in that Doom Patrol and Black Orchid are part of broader comics universes, themselves under the aegis of broader DC Comics continuities. Under these constraints it would be fair to suggest that there is only so much each could do in terms of bending, distorting, reassembling, and revising the powers, experiences, inner worlds, and embodiedness of Jane and Sue. Moore, on the other hand, presents a character of his own design in a broader diegetic universe, also of his own creation. And while Moore, perhaps more so than either Morrison or Gaiman, reformulates entire traditions, chronicles, and histories, a revisionist's work needs to assume certain preconditions in order to revise them. Moore certainly does make a concerted effort to decentralize history, as a grand narrative with a distinct, discrete source, either purely masculine or feminine, Western or non-Western. An equally inextricable conclusion that redounds is the fact that Moore still presents his new omnistories through the auspices of received history. Indeed, this historiographical revisionism is an essential narrative and aesthetic design mandate of the entire series. This paper holds that it would do well to be conscious of that which deconstructive/ revisionist narratology and aesthetics actually ends up reifying, reproducing, and reinforcing. 


\section{CONCLUSION}

The above analysis has attempted to draw critical attention to comics that are more academically disregarded in the oeuvres of their respective writers, all of whom are considered revolutionaries of the medium, and which have interesting connections in terms of how identity, the body, gender, sex and sexuality are represented.In so doing, this paper attempted to provide insightful comparative close readings of these works in terms of how the representation of an unstable, mutable self relates to questions of gender, sex, identity and embodiedness, with a focus on character and narrative themes related to three specifically chosen case studies. It has endeavored to unfold this analysis using dynamic albeit cogent connections drawn between the aforesaid texts and the pertinent theoretical framework of post-structuralist philosophy, psychoanalysis, postmodern historiography and literary criticism. In conclusion, aside from offering an interesting take on how comics can be used to disseminate dense and oftentimes widely regarded 'difficult' post-structuralist theory, this analysis has highlighted the key component in each text's aesthetic and narrative achievement: the paradoxical centrality of de-centredness. They are disordered, de-centrilized specifically through their sex, genders, and identities, thereby challenging the limits and prohibitions of gender-based authority be it violence, trauma, memory, or history, but also more latent metaphysical problems regarding identity and embodiedness. It has also shown that there is a shadow to this enterprise, one predicated on assumed histories and stereotypes that oftentimes circumscribe women in fiction to narrative and aesthetic zero-sum constructions and doublebinds.

\section{References}

(2018, March 26). On Writing the comics - And Queer Character - We Need: Neil Gaiman and N.K. Jemisin in Conversation. Literary Hub. Retrieved from https:// lithub.com/on-writing-the-comics-and- queer-characters-we-need/.

Anderson, K. (2017). Gender Studies and Queer Studies. In M. Smith and R. Duncan (Eds.). The Secret Origins of Comics Studies (pp. 178- 189). New York: Taylor and Francis.

Brisbin, A. \& Booth P. (2013). The Sand/wo/man: The Unstable Worlds of Gender in Neil Gaiman's Sandman Series. The fournal of Popular Culture, 46(1), 20-37. Doi: 10.1111/jpcu.12014

Brooker, W. (2011). Hero of the Beach: Flex Mentallo at the End of the Worlds. Fournal of Graphic Novels and Comics, 2(1), 25-37. Doi: 10.1080/21 504 857.2011.578406 
Campbell, B. (2018, January 18). The Tao of Alan Moore and Grant Morrison. Sequart. Retrieved from http://sequart.org/magazine/68 155/the-tao-of-alan-moore-andgrant- morrison/

Castaldo, A. (2004). "No More Yielding Than a Dream': The Construction of Shakespeare in The Sandman. College Literature, 31(4), 94-110.

Cocca, C. (2017). Superwomen: Gender, Power, and Representation. New York: Bloomsbury Academic.

Comer, T.A \& Sommers, M. (Ed(s).) (2012). Sexual Ideology in the Works of Alan Moore: Critical Essays on the Graphic Novels (ed). North Carolina: Macfarland.

Derrida, J. (1972 [1982]). Margings of Philosophy. Alan Bass (Trans.). Sussex: Harvester Press.

Derrida, J. (1973). Speech and Phenomena and Other Essays on Husserl's Theory of Signs. David B. Allison (Trans). Evanston: Northwestern University Press.

Derrida, J. (1978). Structure, Sign and Play in the Discourse of the Human Sciences. In Alan Bass (Trans.), Writing and Difference. London: Routledge and Kegan Paul.

Di Liddo, A. (2009). Alan Moore: Comics as Performance, Fiction as Scalpel. Jackson: University Press of Mississippi

Dick, M-D. (2013). The Derrida Wordbook. Edinburgh: University of Edinburgh Press.

Domoney-Lyttle, S. \& Lecomte, G. (2017, Novemeber 17). Sand/wo/man: Reading Gender Trouble in Gaiman's Sandman. University of Glasgow Comics Reading Group (blog). Retrieved from https://gucomics.wordpress.com/2017/11/17/sand-woman- reading-gender-trouble-in-gaimans-sandman/.

Elder, R. K. (2007). Gods and Other Monsters: A Sandman Exit Interview and Philosophical Omnibus. In D. Schweitzer (Ed.). The Neil Gaiman Reader (pp. 54-78). Maryland: Wildside Press.

Ferguson, C. (2009). Victoria-Arcana and the Misogynistic Poetics of Resistance in Iain Sinclair's White Chappell Scarlet Tracings and Alan Moore's From Hell. LIT: Literature, Interpretation, Theory, 20(1), 45-64. Doi: 10.1080/10436920802690430

Ferguson, S. (2014). Women and Watchmen: Opening Alan Moore's Refrigerator (Honours thesis). 230. Quachita Baptist University, Arkansas. Retrieved from http://scholarlycommons.obu.edu/honors theses/230.

Gaiman, N. \& McKean, D. (1988). Black Orchid. New York: DC Comics.

Garland, T. S., Branch, K. A., \& Grimes, M. (2016). Blurring the Lines: Reinforcing Rape Myths in Comic Books'. Feminist Criminology, 11 (1), 48-68. Doi: $10.1177 / 1557085115576386$

Green, M. J. A. (2011). "She Brings Apocalypse": Sex, Imagination and Redemptive Transgression in William Blake and the Graphic novels of Alan Moore. University of Nottingham Literature Compass, 8(10), 739-756. Doi: 10.1111/j.17414113.2011.00839.x 
Indick, B. P. (2007). Neil Gaiman in Words and Pictures. In D. Schweitzer (Ed.) The Neil Gaiman Reader (pp. 79-96). Maryland: Wildside Press.

Jasper, M. (2017, April 30). Science Fiction and the Problem with the 'Born Sexy Yesterday' Trope. The Mary Sue. Retrieved from https://www.themarysue.com/bornsexy-yesterday-trope-sff/.

Jaynova. (2012, March 15). I Love Grant Morrison, But....Hellblazer. Retrieved from http://hellblazer.ipbhost.com/topic/9203-i-love-grant- morrison-but/.

Kanayama, K. (2014, January 21). That Alan Moore Interview: A Response for Women Write About Comics. Women Write About Comics. Retrieved from https://womenwriteaboutcomics.com/2014/01/that- alan-moore-interview-aresponse/

Kenealy. R. (2009, Decemeber 23). Alan Moore (and I) Have Some Gender Issues, Scoop. Retrieved from http://www.scoop.co.nz/stories/HL0912/S00 211/alan-mooreand-i- have-some-gender-issues.htm

Kevin. (2013, March 14). Contrarian Fanboy: Alan Moore, What's With All The Rapes? Unleashthefanboy. Retrieved from http://www.unleashthefanboy.com/comics/ contrarian- fanboy- alan-more-whats-with-all-the- rapes/47048.

Kristeva, J. (1974). Revolution in Poetic Language, Part I, The Semiotic and the Symbolic. In V. B. Leitch (Ed.). The Norton Anthology of Theory and Criticism (pp. 2067-2081). New York: W. W. Norton \& Company, inc.

Krueger, R. \& Shaeffer, K. (2011). Alan Moore and Adaptation. ImageTexT 5(4). Retrieved from http://www.english.ufl.edu/imagetext/archives/v5 4/.

Laity, K. A. (2006). Illusory Adversaries? Images of Female Power in The Kindly Ones. In J. L. Sanders (Ed.). The Sandman Papers: An Exploration of the Sandman Mythology (pp. 65-78). Seattle, WA: Fantagraphics.

Linton. J, \& Deries. R. (2015, April 30). The Horror of Rape: Alan Moore's Providence. Factsprovidence. Retreived from https://factsprovidence.wordpress.com/moorelovecraft-comics- annotation-index/the-horror-of-rape-alan-moore-lovecraftand-neonomicon/

Marshall. A.C. (2016). Not So Revisionary: The Regressive Treatment of Gender in Alan Moore's Watchmen. The Downtown Review, 3(2). Retrieved from http://engagedscholarship.csuohio.edu/tdr/vol3/iss2/1

Masserano, E. (2012). "An Act of Social Magic": Class, Gender and Modernity in Alan Moore's From Hell. Retrieved from https://core.ac.uk/display/12 517628

Millidge, G. S. \& Man, S. (2003). Alan Moore: Portrait of an Extraordinary Gentleman. Southend-on-Sea: Abiogenesis Press.

Moore, A. \& O'Neill, K. (1999). The League of Extraordinary Gentlemen: Black Dossier. New York: DC/Wildstorm.

Morrison, G. \& Case, R. (2000). Doom Patrol Vol. 2: Crawling From the Wreackage. New York: DC/Vertigo. 
Morrison, G. \& Case, R. (2004). Doom Patrol Vol 2: The Painting That Ate Paris. New York: DC/Vertigo.

Morrison, G. \& Case, R. (2011, August 22). Morrison on the Death of Comics. Rolling Stone. Retrieved from https://www.rollingstone.com/music/music- news/grantmorrison-on- the-death-of-comics-62761/.

Murray, C. (2010). Signals from Airstrip One: The British Invasion of American Mainstream Comics'. In P. Williams and J. Lyons (Eds.). The Rise of the American Comics Artist: Creators and Contexts (pp. 31-45). Jackson: University Press of Mississippi.

Ó Méalóid, P. (2014, September 9). Last Alan Moore Interview. Slovobooks. Retrieved from http://slovobooks.wordpress.com/2014/01/09/last-alan-moore- interview/.

Rauch, S. (2003). Neil Gaiman's The Sandman and Joseph Campbell: In Search of the Modern Myth. Rockville, MD: Wildside Press.

Reed, A. S. (2008). Through Every Mirror in the World: Lacan's Mirror Stage as Mutual Reference in the Works of Neil Gaiman and Tori Amos. Image-Text 4(1). Retrieved from http://www.english.ufl.edu/imagetext/archives/v4 1/reed/.

Robinson, L. S. (2004). Wonder Women Feminism and Superheroes. New York: Routledge.

Sanders, J. L. (2006). Lesbian Language, Queer Imaginings, and Death: Time of Your Life. In J. L. Sanders (Ed.). The Sandman Papers: An Exploration of the Sandman Mythology (pp. 185-200). Seattle, WA: Fantagraphics.

Sandifer, P. and Eklund, T. (2015). The Comics Works of Neil Gaiman. ImageTexT, 4(1). Retrieved from http://www.english.ufl.edu/imagetext/archives/v4 1/.

Saxton, J. M. (2007). Dreams and Fairy Tales: The Theme of Rationality in A Midsummer Night's Dream and The Sandman. In D. Schweitzer (Ed.). The Neil Gaiman Reader (pp. 22-29). Maryland: Wildside Press. 22-29.

Sharkey, R. (2008). Being Decentered in Sandman: History, Dreams, Gender, and the Prince of Metaphor and Allusion. Image-Text 4(1) Retrieved from http://www.english.ufl.edu/imagetext/archives/v4 1/reed/.

Shaviro, S. (1993). If I Only Had a Brain. Postmodern Culture, 4(1). Doi: 10.1353/ pmc.1993.0052.

Singer, M. (2012). Grant Morrison: Combining the Worlds of Contemporary Comics. Jackson: University Press of Mississippi.

Sneddon. L. (2012, November 24). The Strange Case of Grant Morrison and Alan Moore, As Told by Grant Morrison. The Comics Beat. Retrieved from http://www.comicsbeat.com/the-strange-case-of- grant-morrison-and-alanmoore-as-told-by-grant-morrison/

White, H. (1984). Metahistory. New York: New York UP. 
(2018, March 26). On Writing the comics - And Queer Character - We Need: Neil Gaiman and N.K. Jemisin in Conversation. Literary Hub. Retrieved from https:// lithub.com/on-writing-the-comics-and- queer-characters-we-need/.

Anderson, K. (2017). Gender Studies and Queer Studies. In M. Smith and R. Duncan (Eds.). The Secret Origins of Comics Studies (pp. 178- 189). New York: Taylor and Francis.

Brisbin, A. \& Booth P. (2013). The Sand/wo/man: The Unstable Worlds of Gender in Neil Gaiman's Sandman Series. The Fournal of Popular Culture, 46(1), 20-37. Doi: 10.1111/jpcu.12014

Brooker, W. (2011). Hero of the Beach: Flex Mentallo at the End of the Worlds. Fournal of Graphic Novels and Comics, 2(1), 25-37. Doi: 10.1080/21 504 857.2011.578406

Campbell, B. (2018, January 18). The Tao of Alan Moore and Grant Morrison. Sequart. Retrieved from http://sequart.org/magazine/68 155/the-tao-of-alan-moore-andgrant- morrison/

Castaldo, A. (2004). "No More Yielding Than a Dream': The Construction of Shakespeare in The Sandman. College Literature, 31(4), 94-110.

Cocca, C. (2017). Superwomen: Gender, Power, and Representation. New York: Bloomsbury Academic.

Comer, T.A \& Sommers, M. (Ed(s).) (2012). Sexual Ideology in the Works of Alan Moore: Critical Essays on the Graphic Novels (ed). North Carolina: Macfarland.

Derrida, J. (1972 [1982]). Margings of Philosophy. Alan Bass (Trans.). Sussex: Harvester Press.

Derrida, J. (1973). Speech and Phenomena and Other Essays on Husserl's Theory of Signs. David B. Allison (Trans). Evanston: Northwestern University Press.

Derrida, J. (1978). Structure, Sign and Play in the Discourse of the Human Sciences. In Alan Bass (Trans.), Writing and Difference. London: Routledge and Kegan Paul.

Di Liddo, A. (2009). Alan Moore: Comics as Performance, Fiction as Scalpel. Jackson: University Press of Mississippi

Dick, M-D. (2013). The Derrida Wordbook. Edinburgh: University of Edinburgh Press.

Domoney-Lyttle, S. \& Lecomte, G. (2017, Novemeber 17). Sand/wo/man: Reading Gender Trouble in Gaiman's Sandman. University of Glasgow Comics Reading Group (blog). Retrieved from https://gucomics.wordpress.com/2017/11/17/sand-woman-reading-gender-trouble-in-gaimans-sandman/.

Elder, R. K. (2007). Gods and Other Monsters: A Sandman Exit Interview and Philosophical Omnibus. In D. Schweitzer (Ed.). The Neil Gaiman Reader (pp. 54-78). Maryland: Wildside Press.

Ferguson, C. (2009). Victoria-Arcana and the Misogynistic Poetics of Resistance in Iain Sinclair's White Chappell Scarlet Tracings and Alan Moore's From Hell. LIT:

Literature, Interpretation, Theory, 20(1), 45-64. Doi:10.1080/1043692080 2690430 
Ferguson, S. (2014). Women and Watchmen: Opening Alan Moore's Refrigerator (Honours thesis). 230. Quachita Baptist University, Arkansas. Retrieved from http://scholarlycommons.obu.edu/honors theses/230.

Gaiman, N. \& McKean, D. (1988). Black Orchid. New York: DC Comics.

Garland, T. S., Branch, K. A., \& Grimes, M. (2016). Blurring the Lines: Reinforcing Rape Myths in Comic Books'. Feminist Criminology, 11 (1), 48-68. Doi: $10.1177 / 1557085115576386$

Green, M. J. A. (2011). "She Brings Apocalypse": Sex, Imagination and Redemptive Transgression in William Blake and the Graphic novels of Alan Moore. University of Nottingham Literature Compass, 8(10), 739-756. Doi: 10.1111/j.17414113.2011.00839.x

Indick, B. P. (2007). Neil Gaiman in Words and Pictures. In D. Schweitzer (Ed.) The Neil Gaiman Reader (pp. 79-96). Maryland: Wildside Press.

Jasper, M. (2017, April 30). Science Fiction and the Problem with the 'Born Sexy Yesterday' Trope. The Mary Sue. Retrieved from https://www.themarysue.com/bornsexy-yesterday-trope-sff/.

Jaynova. (2012, March 15). I Love Grant Morrison, But....Hellblazer. Retrieved from http://hellblazer.ipbhost.com/topic/9203-i-love-grant- morrison-but/.

Kanayama, K. (2014, January 21). That Alan Moore Interview: A Response for Women Write About Comics. Women Write About Comics. Retrieved from https://womenwriteaboutcomics.com/2014/01/that- alan-moore-interview-aresponse/

Kenealy. R. (2009, Decemeber 23). Alan Moore (and I) Have Some Gender Issues, Scoop. Retrieved from http://www.scoop.co.nz/stories/HL0912/S00 211/alan-mooreand-i- have-some-gender-issues.htm

Kevin. (2013, March 14). Contrarian Fanboy: Alan Moore, What's With All The Rapes? Unleashthefanboy. Retrieved from http://www.unleashthefanboy.com/comics/ contrarian- fanboy- alan-more-whats-with-all-the- rapes/47 048.

Kristeva, J. (1974). Revolution in Poetic Language, Part I, The Semiotic and the Symbolic. In V. B. Leitch (Ed.). The Norton Anthology of Theory and Criticism (pp. 2067-2081). New York: W. W. Norton \& Company, inc.

Krueger, R. \& Shaeffer, K. (2011). Alan Moore and Adaptation. ImageTexT 5(4). Retrieved from http://www.english.ufl.edu/imagetext/archives/v5 4/.

Laity, K. A. (2006). Illusory Adversaries? Images of Female Power in The Kindly Ones. In J. L. Sanders (Ed.). The Sandman Papers: An Exploration of the Sandman Mythology (pp. 65-78). Seattle, WA: Fantagraphics.

Linton. J, \& Deries. R. (2015, April 30). The Horror of Rape: Alan Moore's Providence. Factsprovidence. Retreived from https://factsprovidence.wordpress.com/moorelovecraft-comics- annotation-index/the-horror-of-rape-alan-moore-lovecraftand- neonomicon/ 
Marshall. A.C. (2016). Not So Revisionary: The Regressive Treatment of Gender in Alan Moore's Watchmen. The Downtown Review, 3(2). Retrieved from http://engagedscholarship.csuohio.edu/tdr/vol3/iss2/1

Masserano, E. (2012). "An Act of Social Magic": Class, Gender and Modernity in Alan Moore's From Hell. Retrieved from https://core.ac.uk/display/12 517628

Millidge, G. S. \& Man, S. (2003). Alan Moore: Portrait of an Extraordinary Gentleman. Southend-on-Sea: Abiogenesis Press.

Moore, A. \& O'Neill, K. (1999). The League of Extraordinary Gentlemen: Black Dossier. New York: DC/Wildstorm.

Morrison, G. \& Case, R. (2000). Doom Patrol Vol. 2: Crawling From the Wreackage. New York: DC/Vertigo.

Morrison, G. \& Case, R. (2004). Doom Patrol Vol 2: The Painting That Ate Paris. New York: DC/Vertigo.

Morrison, G. \& Case, R. (2011, August 22). Morrison on the Death of Comics. Rolling Stone. Retrieved from https://www.rollingstone.com/music/music- news/grantmorrison-on- the-death-of-comics-62761/.

Murray, C. (2010). Signals from Airstrip One: The British Invasion of American Mainstream Comics'. In P. Williams and J. Lyons (Eds.). The Rise of the American Comics Artist: Creators and Contexts (pp. 31-45). Jackson: University Press of Mississippi.

Ó Méalóid, P. (2014, September 9). Last Alan Moore Interview. Slovobooks. Retrieved from http://slovobooks.wordpress.com/2014/01/09/last-alan-moore- interview/.

Rauch, S. (2003). Neil Gaiman's The Sandman and Joseph Campbell: In Search of the Modern Myth. Rockville, MD: Wildside Press.

Reed, A. S. (2008). Through Every Mirror in the World: Lacan's Mirror Stage as Mutual Reference in the Works of Neil Gaiman and Tori Amos. Image-Text 4(1). Retrieved from http://www.english.ufl.edu/imagetext/archives/v4 1/reed/.

Robinson, L. S. (2004). Wonder Women Feminism and Superheroes. New York: Routledge.

Sanders, J. L. (2006). Lesbian Language, Queer Imaginings, and Death: Time of Your Life. In J. L. Sanders (Ed.). The Sandman Papers: An Exploration of the Sandman Mythology (pp. 185-200). Seattle, WA: Fantagraphics.

Sandifer, P. and Eklund, T. (2015). The Comics Works of Neil Gaiman. ImageTexT, 4(1). Retrieved from http://www.english.ufl.edu/imagetext/archives/v4 1/.

Saxton, J. M. (2007). Dreams and Fairy Tales: The Theme of Rationality in A Midsummer Night's Dream and The Sandman. In D. Schweitzer (Ed.). The Neil Gaiman Reader (pp. 22-29). Maryland: Wildside Press. 22-29.

Sharkey, R. (2008). Being Decentered in Sandman: History, Dreams, Gender, and the Prince of Metaphor and Allusion. Image-Text 4(1) Retrieved from http://www.english.ufl.edu/imagetext/archives/v4 1/reed/. 
Corpus Mundi. 2020. Tом 1. No 2 | ISSN: 2686-9055

Представляя тело | https://doi.org/10.46539/cmj.v1i2.14

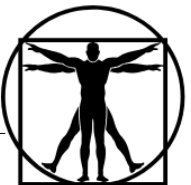

Shaviro, S. (1993). If I Only Had a Brain. Postmodern Culture, 4(1). Doi: 10.1353/ pmc.1993.0052.

Singer, M. (2012). Grant Morrison: Combining the Worlds of Contemporary Comics. Jackson: University Press of Mississippi.

Sneddon. L. (2012, November 24). The Strange Case of Grant Morrison and Alan Moore, As Told by Grant Morrison. The Comics Beat. Retrieved from http://www.comicsbeat.com/the-strange-case-of- grant-morrison-and-alanmoore-as-told-by-grant-morrison/

White, H. (1984). Metahistory. New York: New York UP. 